with printed captions is preferable. Reference was made to the bad influence of the ordinary cinema on children, particularly through displaying life not as service and quiet happiness but as self-indulgence and the mad pursuit of pleasure. Dr. Ballard was emphatic that ordinary broadcasting should not be allowed to curtail a child's necessary quota of sleep or to interfere with his homework.

Though broadcasting as compared with the educational film is comparatively mature, both methods have certain common characteristics and drawbacks. They are not complete educational units; there is no give and take between teacher and taught. They belong to the passive side of school work rather than the active-the impressional rather than the expressional. Both also have their affinity with mass instruction rather than with individual study. The capital virtue of the film is that it enriches the pupil's experience, while that of the radio talk is that it can do for the teacher what he could not do for himself. Dr. S. J. F. Philpott suggested that both methods may tend to diminish the gap between the dull and the brighter pupils.

The closeness with which a crowded audience followed the discussion bore witness to the deep interest in the possibilities of this new technique, and also to the realization of the dangers which attend its abuse in adult life as well as in childhood and adolescence.

\title{
Professionalism in the Modern World
}

$\mathrm{I}^{\mathrm{N}}$ a highly suggestive paper on "Professionalism" read before Section $\mathbf{F}$ (Economic Science and Statistics) at Cambridge on August 19, Mr. T. H. Marshall reviewed the development of the professions and discussed their place and inference in society to-day. According to Herbert Spencer, the history of the professions can be traced back to primitive societies. From the first they were nonmanual, and Mr. Marshall pointed out that their second characteristic was that they were not commercial, an ethical distinction clearly stated by the Greeks. Payment must not be the motive in professional work. The third characteristic of professionalism, the association, follows from the first two. It serves to maintain the power of brain-work to command the produce of manual labour, and it ensures that men, who must not work in order to be paid, are nevertheless paid enough to support them at the right social level. The official aim of a professional association is the preservation of a high standard of efficiency among its members. This is achieved by training and examining all candidates for admission and by obtaining privileges as against all non-members, which may amount to a legal monopoly. Such rights can only be claimed where the profession is based on a body of special knowledge or on a scientific technique which can be imparted in training colleges and tested by examinations. The typical professional association is a body that controls the application of science to the service of society.

In spite of this corporate responsibility to society, the professions are by tradition intensely individualistic, and the close personal relation of trust between the professional man and his client has proved an obstacle to the enlistment of the professions in the service of the State. Under the growth of science, the evolution of capitalism and the advance of democracy towards the social service State, not only have many new professions been developed but also the part played by personal character and tradition in the older professions has diminished. Capitalism requires professional men to work for impersonal corporations and may make him an employee. Democracy is leading the professional men to study the whole social background of the problems confronting him, and the professions are being transformed from strongholds of narrow individualism into most hopeful agencies for scientific social planning.

Simultaneously, Mr. Marshall pointed out, the antithesis between commerce and the professions has been greatly weakened. While the professions have been enlisted in the service of trade, the administration of trade is becoming professionalized. The salaried employees of big businesses are, like the professional man, neither capitalists nor wage-earners. Mr. Marshall suggested that they might become merged into a homogeneous social group, working not for profit, but for economic security, and out of interest in the job, a group favouring rational planning in public life, and individual freedom in private life, a group opposed to war whether between nations or between classes. There is much in common between professionalism in its modern form and some parts of the theory underlying Fascism. Moreover, if this new class is to be effective, either its tactics must be Fabian in the extreme or it must seek allies. Mr. Marshall suggested that the vital question is the attitude this new class is inclined to take up towards the conflict between capital and labour, or whether it is likely to evolve a system of its own differing from that advocated by either of the two contending parties. 